\title{
The Investigation of Some Soil and Morphological Properties of Trees in Conversion of Marsh into Eucalyptus camaldulensis (Dehn) Different Ages Plantation, (Mediterranean Region - Turkey)
}

\author{
Ceyhun GÖL*®, Meliha ÇİÇEK \\ Çankırı Karatekin University, Faculty of Forestry, 18200, Çankırı, TURKEY \\ *Corresponding author: drceyhungol@gmail.com
}

Received Date: 23.05.2018

Accepted Date: 06.05.2019

\section{Abstract}

Aim of study: To determine soil and tree morphological properties in eucalyptus forests of difference between three age groups.

Area of study: This research was carried out in eucalyptus plantation that has been established for both marsh rehabilitation and agro-industrial purposes.

Material and Method: In each sampling plot (select randomly from three differently aged plantation forests.), soil properties and morphological characteristics of thirty-six trees were investigated.

Main results: According to the obtained findings, the soil properties $(0-30 \mathrm{~cm})$ changed with the increasing age of the plantation. There was a little difference in the soil properties $(30-60 \mathrm{~cm})$. Investigations on the morphological characteristics of seedling found average diameters $\left(\mathrm{d}_{1.3}\right)$ of 11.7 $14.5-21.5 \mathrm{~cm}$, in the plantations aged and average lengths of $11.0-15.8-21.7 \mathrm{~m}, 3$, 5, and 9 years-old respectively. The morphological properties of trees were statistically significant at the 0.05 level.

Highlights: Rapid development in tree height in the early years, followed by rapid growth in diameter in the sapling years is understood. The soil properties of the research area were determined to be quite suitable for eucalyptus species.

Keywords: Eucalyptus, Industrial Plantation, Site Requirements, Soil.

\section{Bataklıktan Eucalyptus camaldulensis (Dehn) Plantasyon Ormanına Dönüştürülen Alanda Bazı Toprak ve Ağaç Morfolojik Özelliklerinin İncelenmesi (Akdeniz Bölgesi - Türkiye)}

$\ddot{O} \mathbf{z}$

Çalışmanın amacı: Bu çalı̧̧manın amacı, üç farklı dikim zamanına sahip Okaliptüs plantasyon orman sahalarında, ağaçların bazı morfolojik özellikleri ve toprak özelliklerinin incelenmesidir.

Çalışma alanı: $\mathrm{Bu}$ araştırma, Tarsus-Karabucak Eucalyptus camaldulensis (Dehn) endüstriyel plantasyon sahasında yürütülmüştür.

Materyal ve Yöntem: Araştırmada, üç farklı yaş grubu (3 - 5 - 9 yaş) plantasyon sahalarında, tesadüfi parsellerde birer örnekleme alanı belirlenmiştir. Örnekleme alanlarda, toprak özellikleri ve 36 ağaçta bazı morfolojik özellikler araştırılmıştır.

Sonuçlar: Elde edilen bulgulara göre yüzey toprakları orta ve hafif bünyeli, toprak reaksiyonları alkali ve orta alkali, kireç miktarı \%25 - 59, tuzsuz, organik madde miktarı \%2.02 - 3.68, hacim ağırlığ 0.96 1.06 gr.cm $^{-3}$ özellik göstermiştir. Fidanların morfolojik özellikleri incelendiğinde ortalama çaplar $3-5$ ve 9 yaş gruplarında sırasıyla $11.7-14.5-21.5 \mathrm{~cm}$, ortalama boylar ise aynı yaş sıralamasına göre 11.0 15.8 - $21.7 \mathrm{~m}$ dir. Farklı yaş gruplarına ait ağaçların morfolojik özellikleri istatistiksek olarak önemli fark göstermiş̧tir $(\mathrm{P}<0.005)$.

Önemli vurgular: Ağaçların erken yaşlarda hızlı boy gelişimi, ilerleyen yaşlarda ise hızlı çap gelişimi yaptıkları anlaşılmıştır. Okaliptüs türü için araştırma alanı toprak özelliklerinin oldukça uygun olduğu ve buna bağlı olarak dikilen fidanların yüksek çap ve boy gelişim gösterdikleri belirlenmiştir.

Anahtar Kelimeler: Okaliptüs, Endüstriyel Ağaçlandırma, Yetişme Ortamı, Toprak. 


\section{Introduction}

Industrial forest plantations are commercial plantations which utilize fastgrowing forest tree species that are planted inefficient and congregate areas and are aimed to produce large quantities of raw wood at the end of the administration within a short period (Boydak, 2008). This special type of forestry is concerned with the maximization of wood biomass output per hectare for energy production (Klašnja, Orlović \& Galić 2012). The wood requirement has led to a crucial increase in eucalyptus forests with a total planted area of over 20 million hectares worldwide (Cook, Binkey \& Stape, 2016). Only 7\% of the world forest lands are afforestation of industrial forestry areas, 35\% of the total wood production is supplied from these areas (Herrmann et al., 2015). Significant industrial forest plantations are being established in Chile, Argentine, Venezuela, Brazil, New Zealand, Australia, South Africa, Spain, and Portugal. These countries in the business of developing industrial plantation possess $79 \%$ of such type of afforestation areas. While raw wood material production in natural forests $1 \mathrm{~m}^{3} / \mathrm{ha} /$ year, the production in New Zealand where the industrial afforestation was applied, is 22 $\mathrm{m}^{3} / \mathrm{ha}$, in Chile, Indonesia $20 \mathrm{~m}^{3} / \mathrm{ha}$, and Australia $16 \mathrm{~m}^{3} /$ ha (Sejdjo and Lyon, 2015).

Eucalyptus is a widely preferred species for industrial plantation globally (Herrmann, et al., 2015). Eucalyptus plantations and native forests differ in several aspects. The properties of eucalyptus trees are rapid growth, rapid adaptation, and high production (FAO, 2001; Dohrenbusch, 2011). While studies on industrial eucalyptus plantations in Turkey show continuous improvement to meet the needs for wood or other purposes, their effects on the surroundings, especially in marsh and wetlands, have not been sufficiently researched. Eucalyptus species are also tolerant of severe periodic moisture stress (Liang, Reynolds, Wassie, Collins \& Wubalem, 2016). Because of this characteristic, eucalyptus, as an important production tree species, have been planted on marsh and wetlands in Turkey. Eucalyptus plantations in the Mediterranean and Aegean regions of Turkey are mostly established on poorly drained areas as a way to dry and consequently rehabilitate a marsh. In Turkey, maritime pine plantations were created by the French in 1880 s to encourage the formation of dunes around Lake Terkos. A French company also planted eucalyptus forests for ornamental purposes at stations along the Adana - Mersin railway line that began construction in 1885 . These became the first non - native fast-growing plantations. Later, 885 hectares of eucalyptus plantation was built in Tarsus - Karabucak in 1939 to dry a marsh (Özkurt, Özkurt \& Tüfekçi 2002). The eucalyptus species, known for its rapid development is grown in the Mediterranean and Aegean regions of our country and is important, as it is being subjected to private sector operations as well as governance operations. The rapid growth of eucalyptus, the lower plantation, and maintenance costs; its adaptability to living in poorly growing environments, especially poorly drained areas, have attracted the attention of private sector operators as well. The planting of the Karabucak eucalyptus tree plantation in the marsh area caused it to be recognized by the local people as a "marsh tree" or "malaria tree". However, the recent realization that eucalyptus cultivations are a profitable operation has resulted in the insurance of agricultural production and availability of the market for wood operations for the economic purpose has intensified (Özkurt et al., 2002). The most commonly used type of industrial eucalyptus plantations in Turkey is $E$. camaldulensis. As a result, research is done on the annual production volume of this species found it to reach to values of 49.3 $\mathrm{m}^{3} /$ year per hectare (Avcioğlu, 1990; Yıldızbakan and Saraçoğlu, 2008). The irrigation issue has been discussed in the eucalyptus forests. Souza, Gonçalves and Almeida (1999) indicated that the morphophysiological variations existing in plants of E. camaldulensis under different water deficit conditions. Research has shown that irrigation yields positive results in terms of growth increments (Özkurt et al., 2002).

Eucalyptus species are planted widely in the tropical and temperate regions (Yusong et al., 2010). Their planting is constrained by their limited cold tolerance and ecological 
demands: They have the processed in good feature, a capacity to absorb large quantities of nutrient and water, show rapid development in deep soil where the distribution of annual rainfall during the vegetation period is good and the average temperature in the coldest month does not exceed $-2{ }^{\circ} \mathrm{C}$. Eucalyptus thrives better than other tree species in areas with high groundwater.

E. camaldulensis (Dehnh) are naturally found at altitudes of $20-700 \mathrm{~m}$ and generally in flat and low sloped lands (Williams and Woinarsky, 1997; Göksuakar, 2002). It grows in a wide range of climatic conditions from warm to hot, semi-moist to semi-dry. Mean precipitation ranges between $250-600 \mathrm{~mm}$ in their natural environments. The species is able to resume normal growth in typically sandy, alkaline, moderately saline soil and in soil with groundwater available at root level during vegetation season (Williams \& Woinarsky, 1997). For a successful plantation deep (more than 100 cm) soil depth is preferred (Öztürk, 1994).

Eucalyptus may be used in coastal areas of $250 \mathrm{~m}$ elevations and lands with up to $15 \%$ slopes in Mediterranean and Aegean regions of Turkey in reforestation studies. However, for an efficient industrial plantation land elevated to $50 \mathrm{~m}$ has been recommended. Jelić et al. (2014) indicated that for a successful plantation in Mediterranean regions, several important properties must be fulfilled, in particular, suitable species and soil characteristics. The first eucalyptus afforestation for economical purposes was built in 1939 in an area of 885 ha in the Tarsus - Karabucak region. It is stated by the General Directorate of Afforestation and Erosion Control (Repealed) that the first afforestation activities based on a forest management plan began in 1955. The cultivated forest areas of eucalyptus are mainly located in the Eastern Mediterranean part of Turkey. (Öztürk, 1994). The epithet "malaria tree" is given by the people, as it is used in Turkey for the purpose of drying marshes in areas where dune disease and malaria are common. In light-bodied deep and less stony soils and can show rapid development features. It is a typical light tree. E. camaldulensis, the species most compatible with growing conditions in our country is known to be suitable for pulp and paper industry (Ayata, 2008). Eucalyptus plantations in the study areas are harvested every ten to fifteen years, generally for rotations. As a result of this, it is to be expected that the ecological effects (nutrient depletion, biological condition, reduction of total water yields) attributed to Eucalyptus plantations, especially the effects on soils, will be related to these intensive harvesting (Madeira, 1989).

The aim of this study was to investigate soil and three morphological features of eucalyptus plantation in different planting age groups (3 - 5 - 9 years-old). At the same time, it is a comparative study of the stand characteristics of these plantations. Our goal is to present the first study focusing on the site characteristics of E. camaldulensis plantation in Turkey and to ensure its proliferation in other areas with similar ecological conditions.

\section{Material and Methods}

Study Area Description

The study area is located in the Eastern Mediterranean region of Turkey, in the Mersin Province, the Tarsus District, in the quarters of Karabucak, Yeşiltepe and Kulak (Fig. 1). Eucalyptus forest area is within the Karabucak Forest Planning Unit under Tarsus Forest Enterprise boundaries. This forest area (885 ha), started planting eucalyptus species in 1939 and bears the nature of being the first in Turkey. The general area is 715 ha, out of which 680 ha is productive plantation forest, 32 ha consists of agricultural, settlement, road, drainage channels and similar areas (Anonymous, 2016a). The research area has been subject to eucalyptus plantation for many years. It's a land with an average altitude of $10 \mathrm{~m}$ and a flat and semi-flat $(0-2 \%)$ and sloping plains. Due to the fact that it is a bottomland, drainage channels are used in an attempt to prevent the base water from rising, especially in rainy periods. The study area is afforested because it is a marshy area formed by the drying of the Lake Rhegma. The fields formed from sediment deposit with unknown defining horizons, which are transported by 


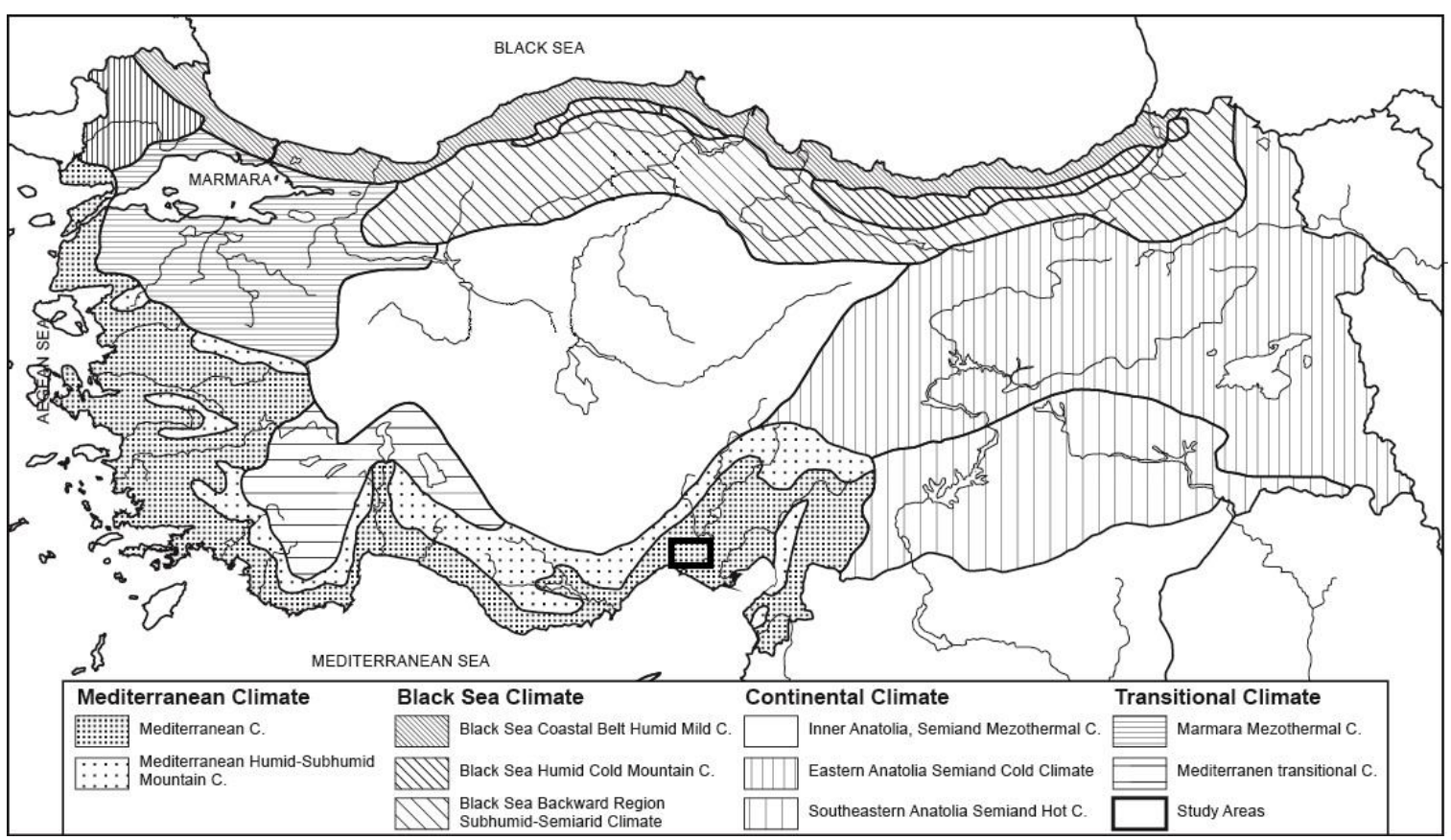

Figure 1. Study area in a Mediterranean climate region (Atalay, Efe \& Öztürk 2014)

Eucalyptus afforestation area is under the influence of the Mediterranean climate. The annual average temperature is $17.9{ }^{\circ} \mathrm{C}$, the annual average precipitation is $602.8 \mathrm{~mm}$. Summer annual precipitation total is $5.7 \%$. The average annual precipitation amount during the vegetation period is $16.8 \mathrm{~mm}$. Most of the rainfall is in winter and summer aridity is experienced in the region (Anonymous, 2016b).

\section{Land-Use History and Plantation Works of the Study Area}

The area that is known today as Karabucak eucalyptus afforestation area was historically Lake Rhegma. People living in and around Tarsus have used the Rhegma Lake as a natural harbor and benefited from all the blessings of the ancient civilization. The historic Kydnos River, which flows through the middle of Tarsus, flooded city. Later, due to a very large flood in the sixth century A. D., the river bed was changed and redirected to the east of the city by the order of the Byzantine Emperor Justinianus. Very little water was added to the bed of Kydnos River, which passed through the city and fed Rhegma. Thus, with the cutting of the main source of water supply that feeds the lake, the lake began to gradually lose its function and turned into a marsh. Today, these areas filled with silt and irregular reeds around water ponds are called Karabucak and Aynaz Marsh by the people of Tarsus (Polat et al., 2011).

In a report prepared by the Ministry of Economy and Commerce (Repealed), Mining Technical Institute in 1936 it was stated that Tarsus Karabucak Marsh might be afforested with eucalyptus trees. Thus the marsh could be improved, and industrial wood could be produced. Accordingly, afforestation studies began in 1939. In an area of 885 ha in total, the marsh was dried for our country's first industrial afforestation, Karabucak eucalyptus plantation (Fehmi Güresin Forest), the need for mine poles was met. In line with this, a large potential agricultural area has been created around it because of transpiration by eucalyptus trees. Which gives off too much water to air with success of the eucalyptus plantations, Tarsus Eucalyptus Research Station Directorate, now called Eastern Mediterranean Forestry Research Institute (EMFRI) was established in 1967. Much research was subsequently 
conducted on eucalyptus. The first yield from the eucalyptus forests was obtained in 1944 and since then has been managed by Karabucak Forest District Headquarter regularly (Polat et al., 2011).

\section{Experimental Design, Sampling and} Laboratory Analyses

During the first phase of the study, climate, topographic map, Digital Elevation Model (DEM), geological map, research and project information covering the field were collected and evaluated. According to the information obtained from previous research and projects, sampling stands were determined in the eucalyptus forests areas. Sampling plots $(20 \times 20 \mathrm{~m})$ in each sampling stands were determined from three randomly located sites of 3 - 5 - and 9 - year-old Eucalyptus plantations (3 year-old, compartment no. 135,5 year-old, compartment no 130, and 9 year-old, compartment no. 110) (Fig. 2). From the 36 trees in sampling plots, the diameter at breast height (DBH) and height were measured. A millimeter caliper was used to measure the breast height diameter $\left(d_{1.3}\right)$. For this purpose, two measurements perpendicular to each other were taken at chest level $\left(\mathrm{d}_{1.3}\right)$ and have been averaged. Full-length measurements were taken from the soil surface to the terminal shoot end of the tree's buds. Trees whose trunks were injured or cracked, or had broken hills, or trees with forked bodies and abnormal crown structure were not included in the sample. From soil profile in each sampling plots undisturbed (using $100 \mathrm{~cm}^{3}$ metal cores) and disturbed soil samples were collected from $0-30 \mathrm{~cm}$, $30-60 \mathrm{~cm}$, and $60-90 \mathrm{~cm}$ layers deep. The forest and soil inventory were carried out from June to July 2016.

Soil samples were analyzed according to the texture (Bouyoucos, 1951), available water capacity (Cassel and Nielsen, 1986), soil organic matter using the Walkley - Black method (Nelson and Sommers, 1996), soil reaction $(\mathrm{pH})$ (Thomas, 1996), electrical conductivity (EC) (Rhoades, 1996), lime $\left(\mathrm{CaCO}_{3}\right)$ (Loppert and Suarez, 1996), bulk density (Blake and Hartge, 1986).

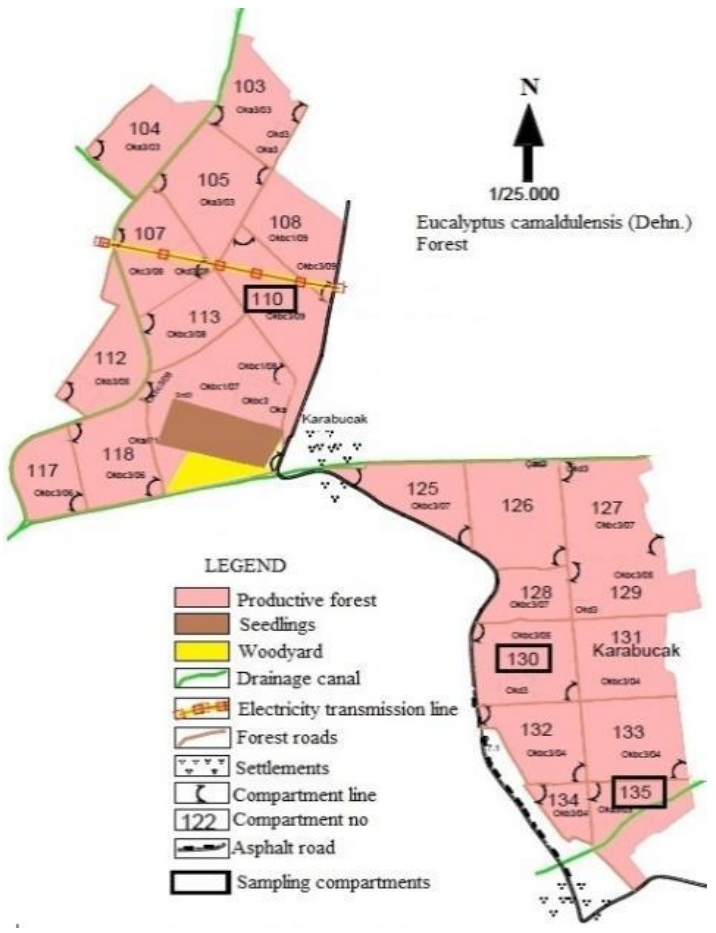

Figure 2. Sampling compartment in $E$. camaldulensis (Dehnh) plantation forest

\section{Statistical Analyses}

The descriptive statistics for tree morphological properties in terms of different age groups were calculated using the SPSS 20.0 (IBM Corporation software). To assess differences among these properties were analyzed using one-way ANOVA tests with Duncan's multiple range tests for multiple comparisons at $\mathrm{P}<0.05$. Some age classes included the following age ranges: 135: 3 age, 130: 5 age, and 110: 9 age which was calculated for sample plots. The oneway ANOVA and the Kolmogorov-Smirnov tests were carried out using the Proc Anova and Proc Capability procedures of the SAS/ETS v9 software (SAS Institute Inc., 2012).

\section{Results and Discussion}

Descriptive Statistics

The descriptive statistics for morphological characteristics of trees to the three different planting years can be seen in Table 1. DBH for the three different planting years (3 - 5 - 9-year-old) were $11.72 \mathrm{~cm}$, $14.58 \mathrm{~cm}$, and $21.52 \mathrm{~cm}$, respectively (Table 1). The DBH as stand characteristic significantly affected by the planting age and other site characteristics for sample plots $(\mathrm{F}=77.702, \quad \mathrm{P}<0.05)$. Among stand age classes, there were significant differences 
$(\mathrm{F}=82.63, \mathrm{P}<0.05)$, and the mean total height were ranked and grouped as follows (Table 1): (3 -year-old; $11.00 \mathrm{~m})<(5$-year-old; $15.88 \mathrm{~m})<$ and (9-year-old ; 21.77m). Results of the one-way ANOVA test showed that the DBH and total height mean values were different by planting ages ordering 3 -yearold $<5$-year-old $<$ and 9 -year-old.

\section{Evaluation of Soil Properties According to Different Planting Years}

Soil characteristics of compartments related to the three different planting years (3 - 5 - 9-year-old) selected for the study were evaluated comparatively. Soil properties under these three eucalyptus stands are given in Table 2. The research area soils consist of alluvial materials brought from Berdan brook. The sand ratio of the soil is high and light in texture. The lowest amount of sand (25-28\%) was measured in the soil of the sampling plot in the 9-year-old plantation. The highest (40 - 50\%) amount of sand was determined in the sampling plot of 3 year-old plantation (Fig. 3 a). In general, soil showed medium texture and clay soil properties (Table 2). In the study area, although the level of groundwater rises to the root zone in rainy periods, the trees could show stagnant water resistance. The variation in the amount of sand and soil organic matter in the soil of the study area has affected in the surface soil properties. Gürses, Ertaş, Gülbaba \& Özkurt (1994) and Özkurt et al., (2002) indicated that eucalyptus species showed rapid growth in sandy loam, sandy clay loam soils of dune land and limestone bedrock found in the Mediterranean region in Turkey. On the other hand, eucalyptus was grown in clay soil in this region, but it was understood that it could not show rapid growth.

Table 1. Results of one-way ANOVA test with Duncan multiple range tests for multiple comparisons at $\mathrm{P}<0.05$. Means with the different letter on a given row are significantly different $(\mathrm{P}<0.05)$ from each other

\begin{tabular}{|c|c|c|c|c|c|c|}
\hline \multirow{2}{*}{$\begin{array}{l}\text { Tree Morphological } \\
\text { Properties }\end{array}$} & \multirow{2}{*}{$\begin{array}{l}\text { Stand } \\
\text { No }\end{array}$} & \multicolumn{3}{|c|}{ Groups } & \multirow{2}{*}{$\begin{array}{c}\mathrm{F} \\
\text { value }\end{array}$} & \multirow[t]{2}{*}{$P$} \\
\hline & & $\mathrm{a}$ & $\mathrm{b}$ & c & & \\
\hline \multirow{3}{*}{$\begin{array}{l}\text { Diameter at breast } \\
\text { height }(\mathrm{DBH})(\mathrm{cm})\end{array}$} & 135 & 11.7222 & & & \multirow{3}{*}{77.702} & \multirow{3}{*}{$\mathrm{P}<0.05$} \\
\hline & 130 & & 14.583 & & & \\
\hline & 110 & & & 21.5278 & & \\
\hline \multirow{3}{*}{ Total height (m) } & 135 & 11.0000 & & & \multirow{3}{*}{82.630} & \multirow{3}{*}{$\mathrm{P}<0.05$} \\
\hline & 130 & & 15.888 & & & \\
\hline & 110 & & & 21.7778 & & \\
\hline
\end{tabular}

a

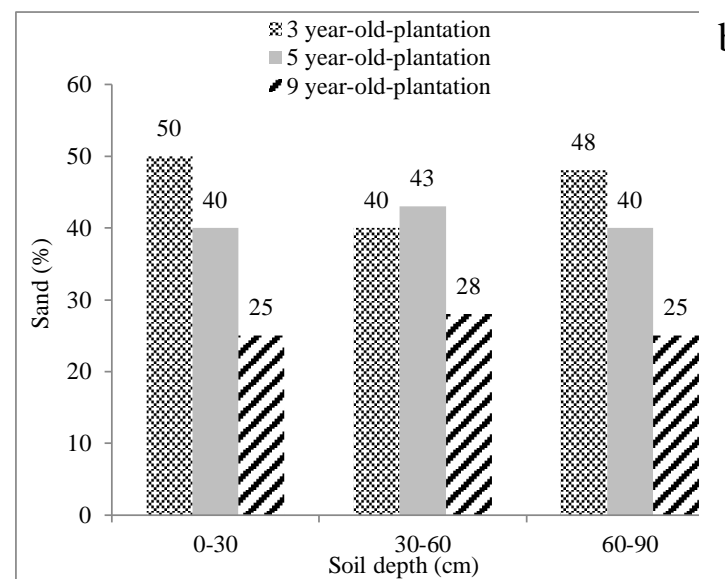

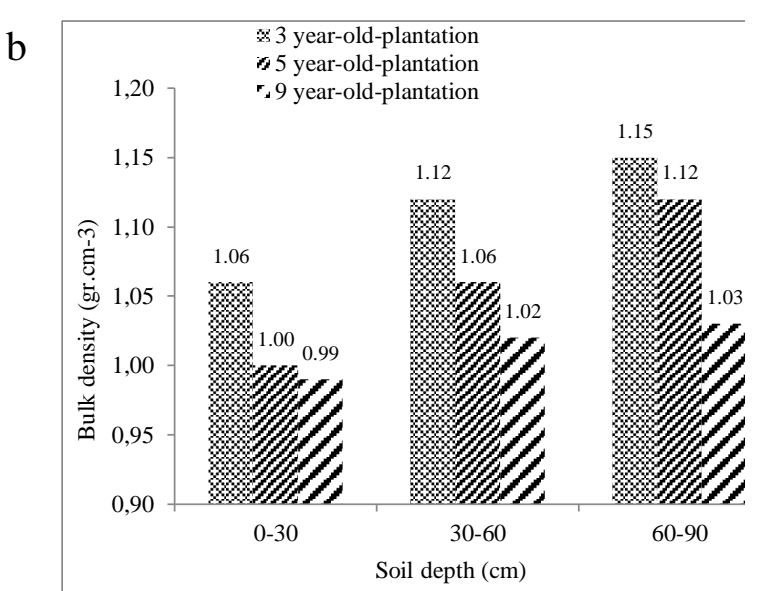

Figure 3. a - Amount of sand in soils in the sampling compartments of the research area, b Bulk density variation of soils in the sampling compartments

When the research area sampling compartments are examined the deepest soils $(120+\mathrm{cm})$ were seen in the plantation aged 9 years. In general, it was determined that the soil depth of the research area was sufficient for the eucalyptus growing in all three sampling areas. Despite the fact that there is a basin water problem that periodically 
restricts physiological depth, it is understood that it does not constitute a problem for eucalyptus as the plant is resistant to this negative effect.

The bulk density of the surface soil in the 9-year-old eucalyptus plantation was found

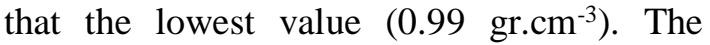
larger soil organic matter content observed in the 9-year-old plantation area might be a probable reason for the smaller bulk density in this stand. A similar smaller bulk density of soil under 9 -year-old eucalyptus plantation compared with other land uses was also reported by Temesgen, Gonzalo and Turrion (2016). The highest bulk density value $\left(1.15 \mathrm{gr.cm}^{-3}\right)$ was found in plantations of 3 year-old, between 60 and $90 \mathrm{~cm}$ soil depth (Table 2) (Fig. 3b). The bulk density of the surface soil in the study area was generally low. It has been determined that the bulk density increases with increasing soil depth. The bulk density of the subsoil is higher than that of the surface soil. Subsoil under 3-5-and 9 - year-old eucalyptus plantations had similar bulk density. The findings are similar to the results of $\mathrm{Wu}$, Liu, Sun, Zhou, Lin \& Fu, (2013), where bulk density of subsoil remained constant under different ages of eucalyptus in China. The depth of soil, the presence of stones, soil type, and the amount of soil organic matter (SOM) and properties of horizons affect bulk density (Polat, et al., 2014). The bulk density of the topsoil in the study area was measured to below depending on the amount of SOM.

a

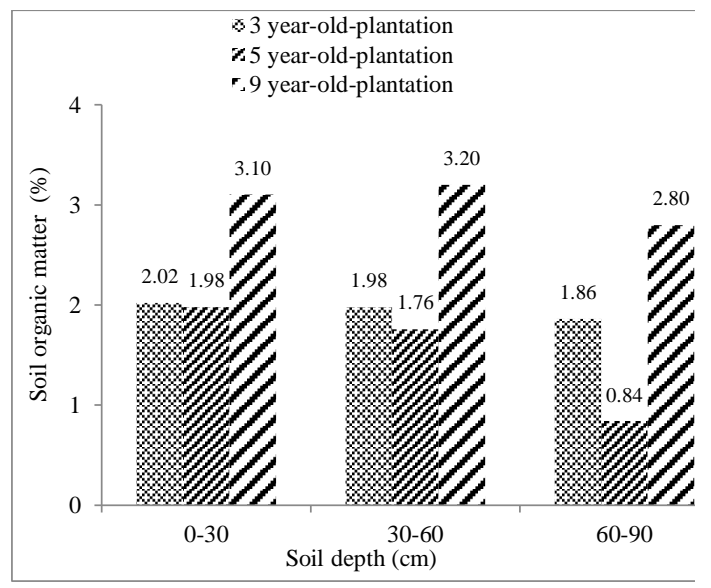

In addition, the increase in the amount of sand directly affected the bulk density. Eucalyptus develops well in deep, mild soils possessing few stones. It is also highly resistant to seasonal groundwater elevations (Dresel et al., 2018). For this reason, it is preferred, especially in the drainage of marsh areas. The study area has alluvial deep soil causing this field of eucalyptus to maintain its fast-growing species.

Fig. 4a shows that the amount of SOM in the soil depths of $0-30 \mathrm{~cm}, 30-60$, and 60 $90 \mathrm{~cm}$. The surface soil of the 9 year - old plantation has the richest amount of SOM and the amounts of SOM's have been measured to be between $2.8 \%$ and $3.2 \%$. As a result of being rich in SOM content intake of a nutrient is high and development is good (Table 2). As for the 5 year - old plantation, the amounts of SOM varies and is inversely proportional. As the soil depth increased, the amount of SOM decreased in all sampling areas (Table 2), (Fig. 4 a). Surface soils of the sampling areas have demonstrated medium and rich SOM contents. Forest plantations generally affect SOM in the surface soil more strongly than in mineral soil (Liang et al., 2016).

Eucalyptus plantations also exhibit consistently higher organic matter and nutrient levels when compared to adjacent lands (Singwane and Malinga, 2012). This effect was also observed in the present study, particularly in 9 year - old eucalyptus plantation area.

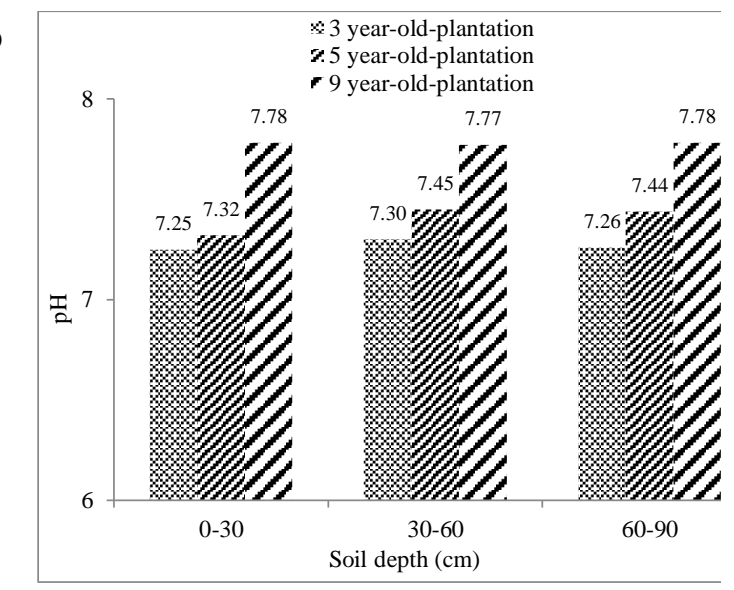

Figure 4. a - Soil organic matter (SOM) contents of soils in the sampling compartments, b - Soil reactions $(\mathrm{pH})$ of soils in the sampling compartments 
The $\mathrm{pH}$ of soils of the research areas was slightly alkaline to medium alkaline $(\mathrm{pH} 7.25$ - 7.78) characteristics (Table 2) (Fig. 4 b). In this respect, the soils of the study area do not create a problem for the eucalyptus plantation.

The site conditions of the research area were directly affected the soil types, amount of SOM, and soil moisture content in critical tension. As the amount of sand in the soil increases, the amount of available water capacity decreases. In the 9-year-old plantation, the surface soil $(0-30 \mathrm{~cm})$ showed the highest amount of plant-available water capacity. This plantation had the lowest amount of sand and the highest amount of SOM in the sampling area. The lowest amount of plant-available water capacity was measured in the topsoil of the 3-year-old plantation (Table 2) (Fig. 5 a). In this plantation, the highest amount of sand for this sampling area (50\%) (Fig. 3 a), and a medium amount of SOM (2.02\%) (Fig. 4 a) were determined, respectively. In addition to improving soil water, soil $\mathrm{pH}$, and soil micro-organisms organic matter supplies essential nutrients to the soil (Weil and Brady, 2016; Singwane and Malinga, 2012). As organic matter input increases in the soil due to increased litter falling from the plantation canopy, micro-organisms break down the organic matter, generating more nutrients, including nitrogen and phosphorus (Bot and Benites, 2005). The available water capacities of soils of the study area showed similar characteristics. The plant available water content of soils demonstrated variance according to the texture and soil organic matter content. Bonilla and Gonzalo (2002) reported that as organic matter level increased, soil water content increased in the Andean foothill site. This higher water availability was translated into higher rates of growth in the forestry plantation. As the amount of sand decreased, the amount of available water capacity and the amount of organic matter increased. In the Mediterranean ecosystem, especially during the vegetation period, the amount of water in the plant root region is important for eucalyptus. a

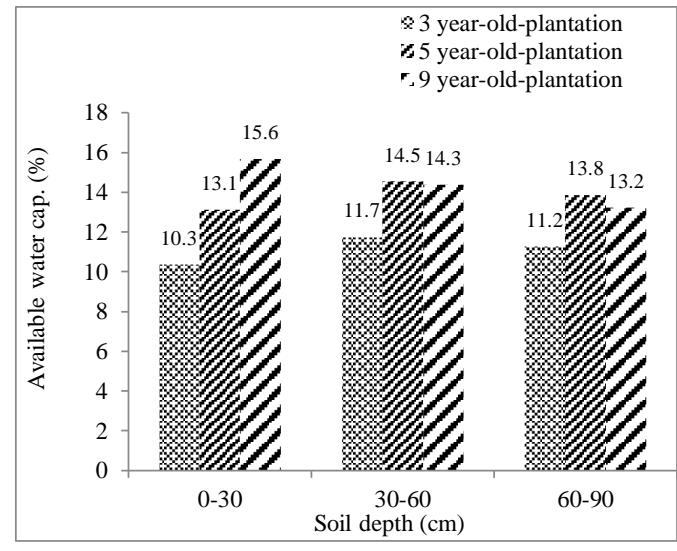

b

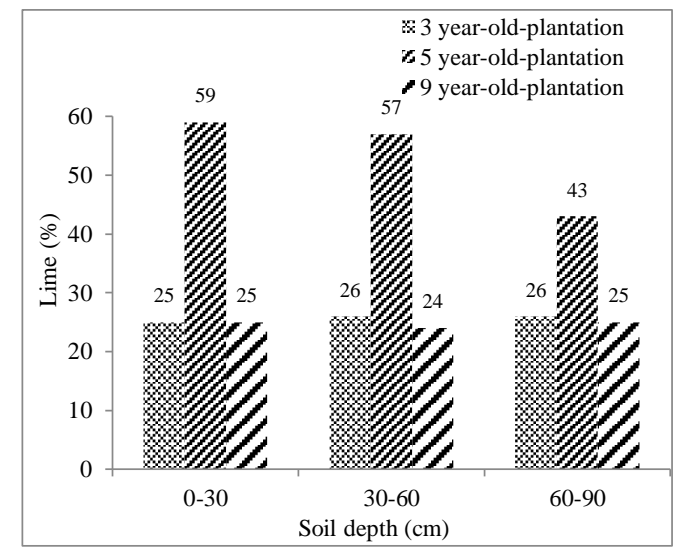

Figure 5. a - Available water capacity of soils in the sampling compartments, b - a Lime variation of soils in the sampling compartments

The amount of lime $\left(\mathrm{CaCO}_{3}\right)$ determined for the different soil depths in the soil profile of the three plantations is presented in Fig. 5 b. These values vary between $24 \%$ and $59 \%$ (Table 2). The highest value $(59 \%)$ was measured in soils of the 5-year-old plantation. The high lime content may be a problem in growing E. Camaldulensis. Although there were eucalyptus plantations on limestone bedrock in the Mediterranean region of Turkey, it was determined that the trees could not grow rapidly.

The results indicate that afforestation with E. camaldulensis caused changes in soil properties, especially surface soils, and the changes were dependent on the age of the plantation. Organic matter, $\mathrm{pH}$, and soil water content are all important considerations of soil health, as there needs to be enough organic matter and nutrients and a favorable $\mathrm{pH}$ range to ensure plant 
growth (Liang et al., 2016). Results show that soil of the 9-year- old plantation had less soil bulk density compared with the 3 and 5 year - old eucalyptus plantations but available water capacity increased with time. Soil organic matter content increased significantly over time in the surface soil layers of E. camaldulensis plantations aged from 3 to 5 or 9 years old. Liang et al., (2016) indicated that eucalyptus could positively impact soil fertility through the decayed litter in areas where the land has been previously degraded by intensive agriculture. Soil $\mathrm{pH}$ in E. camaldulensis plantations did not change significantly with stand age or soil layer. The results demonstrate the increasing development of processes that cause the rehabilitation of soil quality following eucalyptus afforestation of marsh soils. Consequently, amelioration of soil properties in the marsh plantation areas may likely necessitate a significant period of time. Long-term research is needed to understand changes in the soil properties resulting from afforestation with eucalyptus in marsh soils. 
Table 2. Some physical and chemical properties of the soil in the sampling stands of the research area

\begin{tabular}{|c|c|c|c|c|c|c|c|c|c|c|c|c|c|c|}
\hline \multirow[b]{2}{*}{$\begin{array}{c}\text { Sampling } \\
\text { Area } \\
\text { No }\end{array}$} & \multirow[b]{2}{*}{$\begin{array}{c}\text { Compartment } \\
\text { No }\end{array}$} & \multirow[b]{2}{*}{$\begin{array}{c}\text { Tree Age } \\
\text { (Year - Old) }\end{array}$} & \multirow[b]{2}{*}{ Horizon } & \multirow[b]{2}{*}{$\begin{array}{l}\text { Soil } \\
\text { Depth } \\
(\mathrm{cm})\end{array}$} & \multicolumn{3}{|c|}{ Texture (\%) } & \multirow[b]{2}{*}{$\begin{array}{l}\text { Soil } \\
\text { Type }\end{array}$} & \multirow[b]{2}{*}{$\begin{array}{c}\text { Bulk Density } \\
\text { (BD) } \\
\left({\left.\mathrm{gr} . \mathrm{cm}^{-3}\right)}^{-3}\right.\end{array}$} & \multirow[b]{2}{*}{$\begin{array}{c}\text { Available } \\
\text { Water Capacity } \\
(\%)\end{array}$} & \multirow{2}{*}{$\begin{array}{c}\text { Soil } \\
\text { Organic } \\
\text { Matter } \\
\text { (SOM) } \\
(\%)\end{array}$} & \multirow[b]{2}{*}{$\begin{array}{c}\text { Lime } \\
\left(\mathrm{CaCO}_{3}\right) \\
(\%)\end{array}$} & \multirow[b]{2}{*}{$\begin{array}{c}\mathrm{pH} \\
(1: 5 \\
\text { DIW) }\end{array}$} & \multirow[b]{2}{*}{$\begin{array}{c}(\mathrm{EC}) \\
\left(\mathrm{dS} \cdot \mathrm{m}^{-1}\right)\end{array}$} \\
\hline & & & & & Sand & Silt & Clay & & & & & & & \\
\hline \multirow{3}{*}{1} & \multirow{3}{*}{135} & \multirow{3}{*}{3} & $\mathrm{~A}$ & $0-30$ & 50 & 35 & 15 & SL & 1.06 & 10.36 & 2.02 & 25 & 7.25 & 0.75 \\
\hline & & & $\mathrm{C} 1$ & $30-60$ & 40 & 35 & 25 & SL & 1.12 & 11.74 & 1.98 & 26 & 7.30 & 0.62 \\
\hline & & & $\mathrm{C} 2$ & $60+$ & 48 & 32 & 20 & SL & 1.15 & 11.26 & 1.86 & 26 & 7.26 & 0.71 \\
\hline \multirow{3}{*}{2} & \multirow{3}{*}{130} & \multirow{3}{*}{5} & A & $0-30$ & 40 & 30 & 30 & SCL & 0.96 & 13.12 & 1.98 & 59 & 7.32 & 0.54 \\
\hline & & & $\mathrm{C} 1$ & $30-60$ & 43 & 30 & 27 & SCL & 1.09 & 14.55 & 1.76 & 57 & 7.36 & 0.42 \\
\hline & & & $\mathrm{C} 2$ & $60+$ & 40 & 32 & 28 & SCL & 1.13 & 13.85 & 0.84 & 43 & 7.51 & 0.69 \\
\hline \multirow{3}{*}{3} & \multirow{3}{*}{110} & \multirow{3}{*}{9} & A & $0-30$ & 25 & 35 & 40 & CL & 0.99 & 15.66 & 3.10 & 25 & 7.68 & 0.10 \\
\hline & & & $\mathrm{C} 1$ & $30-60$ & 28 & 37 & 35 & $\mathrm{~L}$ & 1.02 & 14.36 & 3.20 & 24 & 7.77 & 0.09 \\
\hline & & & $\mathrm{C} 2$ & $60+$ & 25 & 35 & 40 & $\mathrm{CL}$ & 1.05 & 13.21 & 2.80 & 25 & 7.88 & 0.10 \\
\hline
\end{tabular}

Abbreviations: SL - sandy loam, SCL - sandy clay loam, CL - clay loam L - loam 
Breast Height Diameter (BHD) and Height Properties of Trees According to the Different Planting Years

At the result of breast height diameter (BHD) - measurements carried out on thirty six randomly selected trees in the three groups of the study area, the average BHD value of the trees in the 3 year - old plantation was calculated as $11.7 \mathrm{~cm}$, the average height value as $11.0 \mathrm{~m}$. For the 5 year - old plantation, the average BHD was calculated as $14.5 \mathrm{~cm}$ and the value of the average height as $15.8 \mathrm{~m}$. For the 9 year - old plantation of the average BHD was $21.5 \mathrm{~cm}$, while the value calculated as the average height was $21.7 \mathrm{~m}$ (Fig. 6). According to the results of average BHD and height measurements, the trees showed balanced growth characteristics. Trees appear to have balanced breast height diameter - height growth in the first years, and rapid height growth in middle ages, and stable equilibrium diameter and height growth in later ages. It is noteworthy that trees follow a balanced growth as was seen according to the results of diameter and height measurements of different planting years. While the height increase was high in middle-aged individuals, the increase in diameter and height regained its balance during the later ages. It has been determined that the planted seedlings showed rapid growth in height and diameter in the first years, in the following years the increase in diameter was determined especially.

Measurement of the tree height and BHD specifications and corresponding graphs (Fig. $7 \mathrm{a}, \mathrm{b}, \mathrm{c})$ considering planting in the early years $(0-3$ year - old plantation) of low height - BHD relationship $\left(\mathrm{R}^{2}=0.5693\right)$, the middle and later years $(3-9$ year - old plantation) the strengthening of this relationship $\left(\mathrm{R}^{2}=0.7402\right)$ and $\left(\mathrm{R}^{2}=0.7271\right)$ were determined (Fig. 7 a, b, c).

In terms of climate, soil and other ecological conditions, E. camaldulensis demonstrated characteristics suited to the habitat. Industrial plantations are generally associated with good quality soil properties. This plantation, in particular, may adversely affect soil properties (Liao, Luo, Fang, Chen \& Li (2012); Zhang, Zhang, Yang \& Wu, 2012). Although eucalyptus is a fast-growing species, lack of knowledge on how industrial plantations affect soil quality in marsh areas, in the long run, restrict the probability to create local guidelines on sustainable forestry in Turkey. As it has been specified by Sandoval et al. (2015) eucalyptus has become one of the most planted genera as a result of their high rates of productivity and their adaptability to many different sites and climatic conditions. In the determination of industrial plantation areas to be established with fast-growing species in meeting the need of our country's wood raw materials, selection of areas similar to the ecological characteristics of the research area will increase the rate of success.

According to the results of breast height diameter $(\mathrm{BDH})(\mathrm{cm})$ measurements of examples of trees selected in sampling areas of different planting year, for the plantation of 9 year - old sampling areas the BDH's were between $15-29 \mathrm{~cm}$ and in average was $21 \mathrm{~cm}$, for the plantation of 5 year - old, between $8-23 \mathrm{~cm}$ in $\mathrm{BDH}$ and $14 \mathrm{~cm}$ in average, for the plantation of 3 year - old, between the $8-15 \mathrm{~cm}$ and $11 \mathrm{~cm}$ in average. Growth rates of height $(\mathrm{m})$ of selected trees in sampling areas were demonstrated parallelism to planting years and ages. 


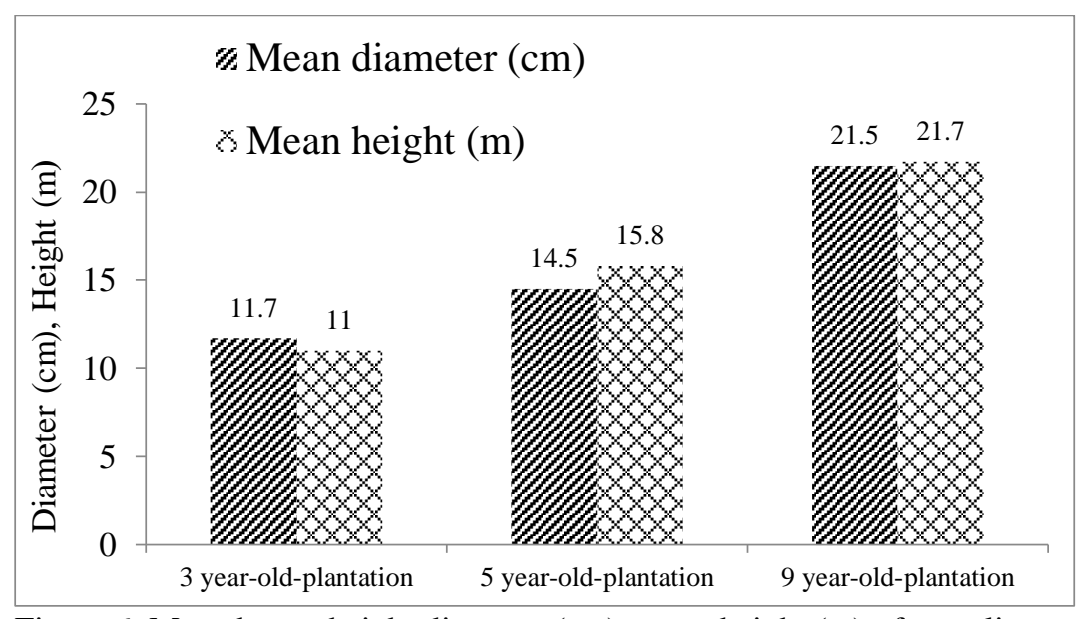

Figure 6. Mean breast height diameter $(\mathrm{cm})$, mean height $(\mathrm{m})$ of sampling trees
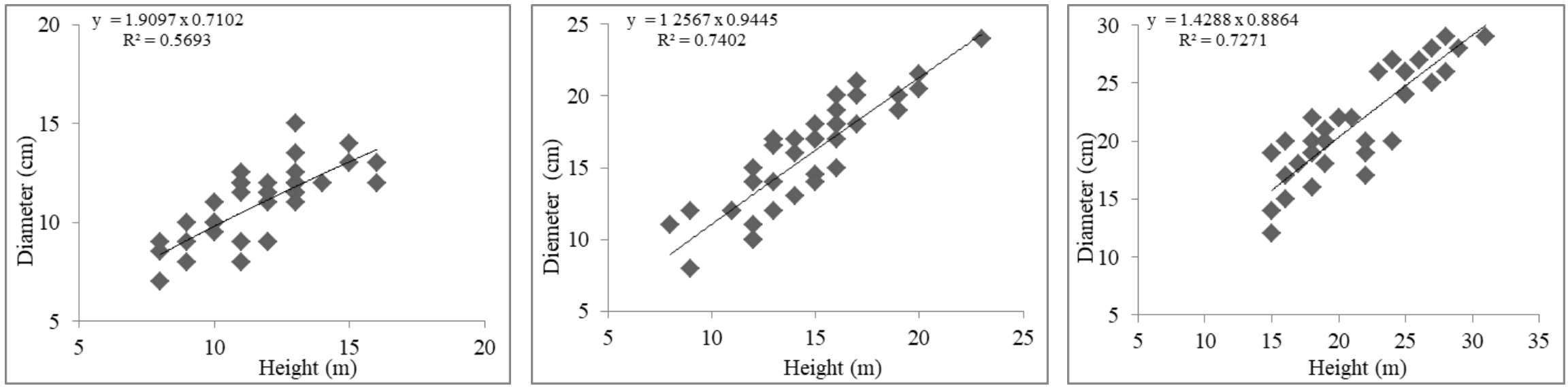

Figure 7. The breast height diameter and height relationship or measured 36 eucalyptus trees in each sampling areas a- 3 year - old plantation, b- 5 year - old plantation and c- 9 year - an old plantation 
When the BDH distributions of the measured trees were examined for 3 year-old plantation it was $13 \mathrm{~cm}$, for 5 year-old plantation $16 \mathrm{~cm}$, and for 9 year-old plantation trees of $18 \mathrm{~cm}$ and $25 \mathrm{~cm}$ were seen to have high frequencies. It is seen that grouping in the frequency distributions of the distributions of $\mathrm{BDH}$ of the trees measured in the plantation of 9 year - old. Accordingly, the high-frequency band of the trees $15-20$ $25 \mathrm{~cm}$ BDH class, and as for low frequency it is determined to have accumulated in $16-22$ - $30 \mathrm{~cm}$ BDH class (Fig. 8 a, b, c).

According to height values of measured thirty - six trees in sampling areas, areas of $12 \mathrm{~m}$ were determined to have a high frequency in the plantation of 3 year-old, 18 $\mathrm{m}$ for the 5 year-old plantation, and $20 \mathrm{~m}$ for the 9 year-old plantation. While variant frequency distributions were seen in height distribution of trees included in the plantation of 3 year-old, the height frequency distributions were seen to have shifted to high height classes for the age group (Fig. 9 $a, b, c)$.

\section{Conclusion}

From this study, results indicated that conversion of marsh and wetlands to eucalyptus plantations changed soil quality based on the mean values of soil physical and chemical parameters, especially surface soils. It is well-known plant cover influences soil properties. In the forest, this influence has been studied mainly for exotic and/or fastgrowing forest tree species (Madeira, 1989) This study demonstrated that soil organic matter content and available water capacity were substantially increased in 9 year - old eucalyptus plantations. They have a reputation for a substantial reduction of total water yields when planted in semi-arid water catchment areas. (Florence, 1986) At the same time, eucalyptus trees are resistant to phreatic fluctuation. The surface soil properties were positively affected due to the age of eucalyptus over a 9 - year-old period. This demonstrates the importance of industrial plantations and the establishment of new eucalyptus forests in the same marsh areas. Eucalyptus species have been growing in the Mediterranean and Aegean region of Turkey and growing eucalyptus in these regions are getting importance because it has been planted both by private and government sectors. For this reason, considering the current high demand of eucalyptus for industrial wood, great cautions should be taken in the conversion of wetland and marsh areas to short-rotation eucalyptus in the Mediterranean region of Turkey

\section{Acknowledgment}

This study was supported by TUBITAK 2209 - A Domestic Research Projects of University Students (project no: 1919B011502612). We thank TUBITAK for its contribution. We would also like to thank the Directorate of the Eastern Mediterranean Forestry Research Institute and the Karabucak Forestry sub-district headquarters for helping with the database and fieldwork.

The authors would like to especially thank anonymous reviewers for their valuable comments and suggestions which improved the quality of the paper. The authors would like to thank Bianka Martinez (native speaker) for her grammatical revision of the manuscript. 
a

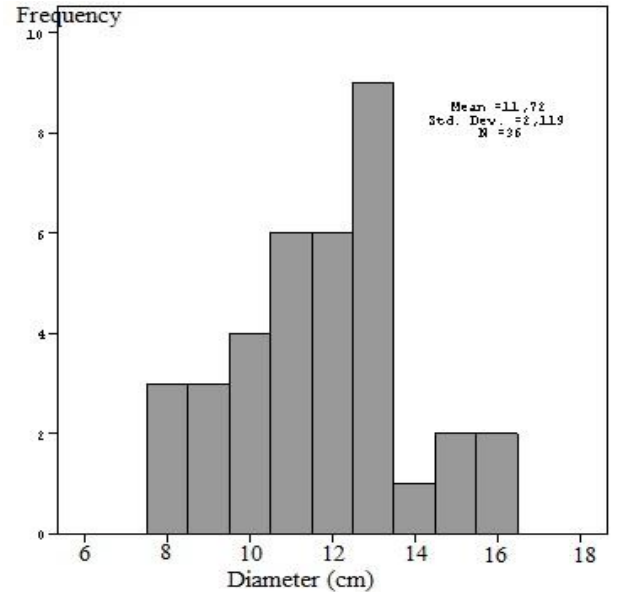

b

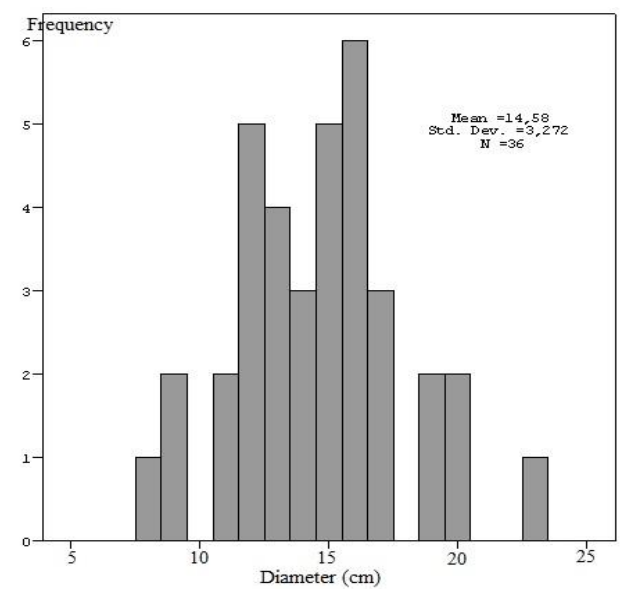

Diameter $(\mathrm{cm})$

b

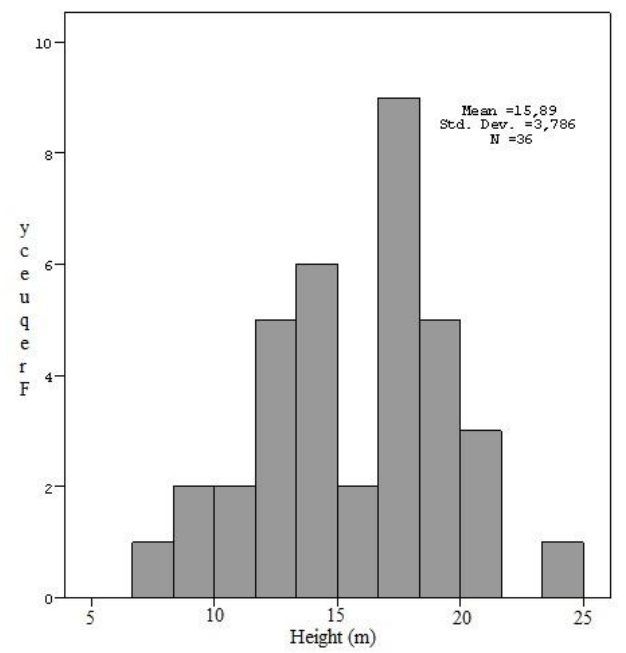

Height $(m)$

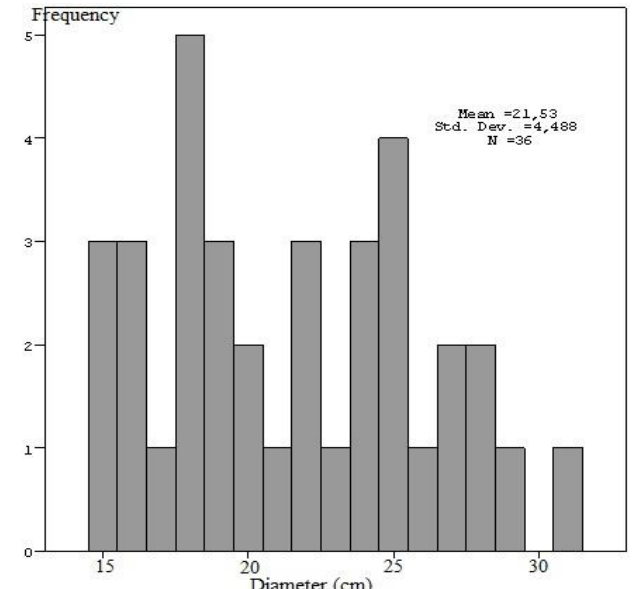

a

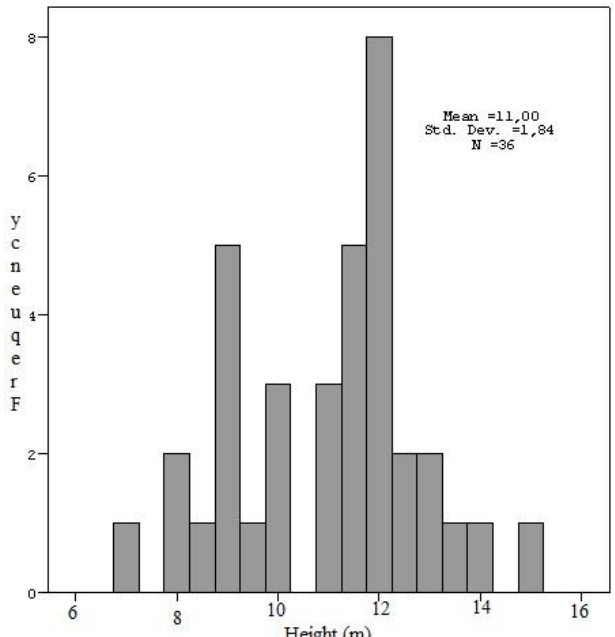

c

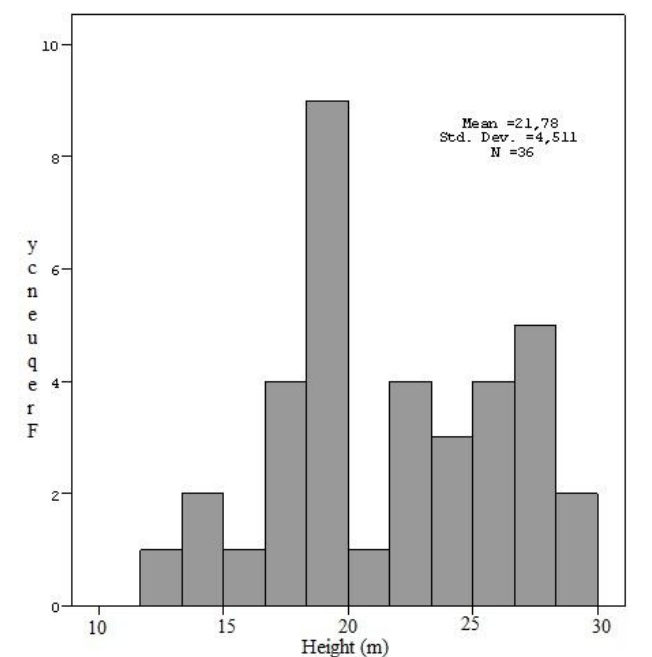

Figure 9. The height frequency distributions of trees a- 3-year-old plantation, b- 5-year-old plantation and c- 9-year-old plantation 


\section{References}

Anonymous. (2016a). Karabucak $4^{\text {th }}$ industrial afforestation application project. Mersin Forest District Directorate, Tarsus Forest Management Directorate, Karabucak Forest Management Conduct, (pp. 75). Tarsus, Turkey.

Anonymous. (2016b). Tarsus meteorological station, meteorological data table. p. 3. OSIBB, General Directorate of Meteorology, Ankara, Turkey.

Avcioğlu, E. (1990). Eucalyptus, breeding, and management. 50th year of eucalyptus breeding in Turkey. Journal of Poplar and Rapidly Developing Foreign Forest Trees Research Institute, 1, 21-50.

Ayata, Ü. (2008). Research of Eucalyptus (Eucalyptus Camaldulensis and Eucalyptus grandis) wood properties and their use in the paper industry. (pp. 105). Postgraduate Thesis. Kahramanmaraş, Turkey. The University of Kahramanmaraş Sütçü İmam.

Atalay, İ., Efe, R. \& Öztürk. (2014). Ecology and classification of Forest in Turkey. The $3^{\text {rd }}$ International Geography Symposium - Geo MED 2013 Procedia - Social and Behavioral Sciences, 120, 788-805.

Blake, G. R. \& Hartge, K. H. (1986). Bulk density, in Klute, A. (Ed.), Methods of Soil Analysis Part 1 Physical and mineralogical methods 2nd ed, SSSA Book Series 5.1, (pp. 363-375). Soil Science Society of America, Madison, USA.

Bonilla, C.A. \& Gonzalo, B.C.U. (2002). Spatial and Temporal Distribution of Precipitation and Soil Water Content at Three Forest Sites of the VIII Region of Chile. Agricultura Técnica (Chilean Journal of Agricultural Research). 62(4), 541-554.

Bot, A. \& Benites, J. (2005). The importance of soil organic matter: Key to drought-resistant soil and sustained food and production. FAO Soils Bulletin: 80. ISBN 92-5-105366-9.

Bouyoucos, G. J. (1951). A recalibration of the hydrometer for making mechanical analysis of soil. Journal of Agronomy, 43, 434-438.

Boydak, M. (2008). Industrial plantations and importance in Turkey. (pp. 1-11). $1^{\text {th }}$ National Eucalyptus Symposium Book, 15-17 April 2008, Tarsus.

Cassel, D. K. \& Nielsen, D. R. (1986). Field capacity and available water capacity, in Klute, A. (Ed.), Methods of Soil Analysis Part 1 Physical and mineralogical methods 2 nd ed, SSSA Book Series 5.1, (pp. 901-924). Soil Science Society of America, Madison, USA.

Cook, R. L., Binkey, D. \& Stape, J. L. (2016). Eucalyptus plantation effects on soil carbon after 20 years and three rotations in Brazil. Forest Ecology and Management, 359, 92-98.
Dresel, E.P., Dean, J.F., Perveen, F., Webb, J.A., Hekmeijer, P., Adelana, S., M. \& Daly, E. (2018). Effect of Eucalyptus plantations, geology, and precipitation variability on water resources in upland intermittent catchments. Journal of Hydrology. 564, 723-739.

Dohrenbusch, A. (2011). The role of deforestation and afforestation for the global carbon sequestration. (pp. 31-57). In: Fehrmann, L., Klein, C. (Ed.), $2^{\text {nd }}$ International Workshop on Forests in Climate Change Research and Policy. Cuvillier Verlag Göttingen, Pietermaritzburg and Durban, South Africa.

FAO, (2001). Mean annual volume increment of selected industrial forest plantation species. (pp. 1-27). by L. Ugalde and O. Pérez. In: FAO, (Ed.) Forest Plantation Thematic Papers, Working Paper 1. Forest Resources Development Service, Forest Resources Division. Rome, Italy. Available at http://www.fao.org/3/a-ac121e.pdf, (accessed July 2016).

Florence, R.G. (1986). Cultural problems of Eucalyptus as exotics. Comm. For Rev. 65(2), 141-163.

Göksuakar, A. (2002). Techniques of growing Eucalyptus seedlings in Tarsus-Karabucak forest nursery. (pp. 10-110). Postgraduate Thesis. Faculty of Forestry, University of Süleyman Demirel, Isparta, Turkey.

Gürses, M. K., Ertaș, M. R. Gülbaba, A. G. \& Özkurt, A. (1994). The Project of research of the development of some eucalyptus species and origins in different salinity soil. (pp. 145). The result report in 1994, Eastern Mediterranean Forestry Research Directorate, Tarsus.

Herrmann, J. D., Opatovsky, I., Lubin, Y., Pluess, T., Regev, E. G. \& Entling, M. H. (2015). Effects of non-native Eucalyptus plantations on epigeal spider communities in the northern Negev desert, Israel. Journal of Arachnology, 43(1), 101-106.

Jelić, G., Topić, V., Butorac, L., Đurđević, Z., Jazbec, A. \& Oršanić, M. (2014). Container size and soil preparation effects on afforestation success of one year old stone pine (Pinus pinea L.) seedlings in Croatian Mediterranean area, Šumarski list, 9(10), 463475.

Klašnja, B., Orlović, S. \& Galıć, Z. (2012). The energy potential of poplar plantations in two spacing and two rotations. Śumarski list, 3(4), 161-167.

Liang, J., Reynolds, T., Wassie, A., Collins, C. \& Wubalem, A. (2016). Effects of exotic Eucalyptus spp. plantations on soil properties in and around sacred natural sites in the 
northern Ethiopian Highlands. AIMS Agriculture and Food, 1(2), 175-193.

Liao, C., Luo, Y., Fang, C., Chen, J. \& Li, B. (2012). The effects of plantation practice on soil properties based on the comparison between natural and planted forests: a metaanalysis. Global Ecol. Biogeogr. 21, 318-327.

Loppert, R. H. \& Suarez, D. L. (1996). Carbonate and gypsum. (pp. 437-476). In: JM Bartels, (Edt.), Methods of soil analysis part 3. chemical methods. SSSA Book Series, No. 5, American Society of Agronomy Inc., Madison, Wisconsin, USA.

Madeira, M. A. V. (1989). Changes in Soil Properties under Eucalyptus Plantations in Portugal. In: Pereira J.S., Landsberg J.J. (eds) Biomass Production by Fast-Growing Trees. NATO ASI Series (Series E: Applied Sciences), 166, Springer, Dordrecht.

Nelson, D.W. \& Sommers, L.E. (1996). Total carbon, organic carbon, and organic matter, in Sparks, D.L. (Ed.), Methods of Soil Analysis. Part 3. Chemical Methods, SSSA Book Ser. 5. 3. (pp. 961-1010). Madison, USA, Soil Science Society of America.

Özkurt, A., Özkurt, N. \& Tüfekçi, S. (2002). Determination of the Eucalyptus Amount of Irrigation Water and Irrigation Interval in Eucalyptus Plantations in Tarsus - Karabucak Region. Eastern Mediterranean Forestry Research Institute, Technical Bulletin 203, 26-46.

Öztürk, A. (1994). The structure and economy of eucalyptus industry in Çukurova region. (pp. 1-147). Postgraduate Thesis. Adana, Turkey. The University of Çukurova.

Polat, S., Polat, O. \& Tüfekçi, S. (2011). The ecological story of the transition from Lake Rhegma to the marsh, from marsh to eucalyptus forests. Ecology 2011 Abstract Book, (pp.1-148). 5-7 May 2011, University of Düzce, Turkey. 248 p.

Polat, S., Polat, O., Kantarc1, M. D., Tüfekçi, S. \& Aksay, Y. (2014). The relationships between height growth and some site conditions in the forest of Cedrus (Cedrus libani A. Rich.) Pinus nigra (Pinus nigra Arnold.) in Mersin-Kadinc1k catchment. Journal of Forestry Research 1(A1), 22-37.

Rhoades, J. D. (1996). Salinity: Electrical Conductivity and Total Dissolved Solids, in Sparks, D.L. (Ed.), Methods of Soil Analysis. Part 3. Chemical Methods, SSSA Book Ser. 5. 3., (pp. 417-436). Soil Science Society of America, Madison, USA.

Sandoval, S., Cancino, J., Esquivel, E., Acuna, E., Rubilar, R. \& Espinosa, M. (2015). Evaluation of damage caused by Ectinogonia buquetti (Coleoptera: Buprestidae) in dendroenergetic plantations of Eucalyptus camaldulensis. Bosque (Valdivia) 36(2), 247-254.

SAS Institute Inc. 2012. SAS/ETS $® 9.3$ User's Guide. Cary, NC, USA: SAS Institute Inc.

Sejdjo, R. A. \& Lyon, K. S. (2015). World forest resources and production. (pp. 23-51). The long-term adequacy of world timber supply. Routledge Revivals, RFF Press, 2 Park Square, Milton Park, Abington, Oxon, OX14 $4 \mathrm{RN}$ and by Routledge, 711 Third Avenue, Newyork, NY 1007, USA.

Singwane, S. S. \& Malinga, P. (2012). Impacts of pine and eucalyptus forest plantations on soil organic matter content in Swaziland -Case of Shiselweni Forests. J Sustain Dev. Afr. 14, 137-151.

Souza, G. M., Gonçalves, A. N. \& Almeida, M. de. (1999). Water deficit in relation to leaf and stem anatomy of Eucalyptus camaldulensis Dehnh. shoots cultivated in vitro. Sci. Agric. 56(3), 723-731.

Temesgen, D., Gonzalo, J. \& Turrion, M. B. (2016). Effects of short-rotation Eucalyptus plantations on soil quality attributes in highly acidic soils of the central highlands of Ethiopia. Soil Use and Management, 32(2), 210-209.

Thomas, G. W. (1996). Soil pH and soil acidity. In: JM Bartels, (Edt.), Methods of soil analysis part 3. chemical methods. SSSA Book Series, No. 5, (pp. 475-490). American Society of Agronomy Inc., Madison, Wisconsin, USA.

Weil, R.R. \& Brady, N.C, (2016). The Nature and Properties of Soils. Fifteenth Edition, Columbus: Pearson Publishing Company ISBN-10: 0-13-325448-8.

Williams, J. E. \& Woinarsky, J. C. Z. (Edt.). (1997). Eucalypt Ecology: individuals ecosystems. (pp. 1-427). Cambridge University Press, The Pitt Building, Trumping ton Street, Cambridge, United Kingdom.

Wu, J.P., Liu, Z. F., Sun, Y.X., Zhou, L.X., Lin, Y. B. \& Fu, A. L. (2013). Introduced Eucalyptus urophylla plantations change the composition of soil microbial community in subtropical China. Land Degradation \& Development, 24, 400-406.

Yıldızbakan, A. \& Saraçoğlu, Ö. (2008). Eucalyptus (Eucalyptus camaldulensis Dehnh.). (pp. 230-243). $I^{\text {th }}$ National Eucalyptus Symposium Book, 15-17 April 2008, Tarsus, Turkey.

Yusong, C., Shenglei, F., Xiaoming, Z., Honglin, C., Yuanhu, S. \& Lixia, Z. (2010). Soil microbial community composition under Eucalyptus Plantations of different age in subtropical China. European Journal of Soil Biology, 46, 128-135. 
Kastamonu Uni., Orman Fakültesi Dergisi, 2019, 19 (2):197-213

Göl and Çiçek

Kastamonu Univ., Journal of Forestry Faculty

Zhang, D., Zhang, J., Yang, W. \& Wu, F. (2012).

microbiological properties. Soil Res. 50, 167Effects of afforestation with Eucalyptus 176.

grandis on soil physicochemical and 